\title{
Modification of heart rate in lactacid anaerobic effort among amateur
}

\author{
athletes
}

\section{Cezar HONCERIU 1, Florin Petrut TROFIN²}

\begin{abstract}
Lactacid anaerobic efforts are frequently encountered in the practice of physical exercises by amateur athletes, while the modification of heart rate in such activities differs from one athlete to another, mainly depending on the training level. The purpose of the paper is to monitor the heart rate in lactacid anaerobic effort and to highlight the immediate modification caused by effort. 15 male amateur athletes performed the race of $200 \mathrm{~m}$, at peak intensity. The modification of heart rate during effort, in 13 of the athletes, did not reach $\mathrm{Hr}_{\max }$ calculated by the formula 220 - age, but it exceeded in case of two of the research subjects.
\end{abstract}

Key words: heart rate, lactacid anaerobic effort

\section{Rezumat}

Eforturile de tip anaerob lactacid sunt frecvent întâlnite în practicarea exercițiilor fizice de către sportivii amatori iar modificarea frecvenței cardiace în astfel de activități diferă de la sportiv la sportiv, în principal, în funcție de gradul de antrenament. Lucrarea are ca scop monitorizarea frecvenței cardiace în efort de tip anaerob lactacid și evidențierea modificărilor imediate cauzate de efort. 15 sportivi amatori, de gen masculin, au realizat proba de $200 \mathrm{~m}$, la intensitate maximală. Modificarea frecvenței cardiace de efort, la 13 dintre sportivi, nu a atins $\mathrm{Fc}_{\max }$ calculată după formula 220 - vârsta, acesta fiind însă depășită la doi dintre subiecții cercetării.

Cuvinte cheie: frecvență cardiacă, efort anaerob lactacid.

\footnotetext{
${ }^{1}$ Lecturer, Al. Ioan Cuza University of Iasi, Romania, Faculty of Physical Education and Sport, Center for Interdisciplinary Research in Human Mouvement Science, email: chonceri@yahoo.fr

${ }^{2}$ Assist. Prof., Al. Ioan Cuza University of Iasi, Romania, Faculty of Physical Education and Sport
} 


\section{Introduction}

Exercise capacity represents the possibility of active muscle tissue of releasing the energy necessary for a mechanical work that is as intense and as longterm as possible. Carbohydrates (ensuring 65-68\% of the energy), fats (ensuring 31-31\% of the energy) and proteins (ensuring $2-3 \%$ in normal conditions and $10 \%$ in extended efforts) represent the food nutritional principles used in muscle metabolism as energetic sources.[18] The metabolic pathways of supporting the effort may be: anaerobic and aerobic (50 times more effective than the anaerobic one in ATP production). The phosphagen system (ATP-CP), lactic anaerobic - providing an ATP mol, the glycolytic system (anaerobic glycolysis) or the lactic acid system - providing three ATP moles, the oxidative system or oxidative phosphorylation, comprising aerobic glycolysis, the Krebs cycle and the system of electron carriers - providing 38 ATP moles are the ergogenetic systems ensuring muscular energy. The macroergic phosphate links of the ATP stores the energy produced, and the muscular ATP deposits are limited to 2-8 mmoles/litre or under $100 \mathrm{~g}$. By degrading macroergic phosphate link, $7.3 \mathrm{kcal} /$ mole are released [1].

The anaerobic exercise capacity represents the body's capacity of achieving efforts at maximum level, using the anaerobic energy, with accumulation of lactate [19]. Very high or maximum intensity, real or apparent misbalance between $\mathrm{O}_{2}$ supplies and demands and $\mathrm{O}_{2}$ debt, the duration under $2 \mathrm{~min}$, the mechanical efficiency between 15 and $16 \%$, the energetic source - the anaerobic phosphagen energetic system where ATP is produced by decomposing phosphocreatine ( $\mathrm{PCr}$ ), exceeding the lactic threshold of 4 mmoles/l and high heart rates of over $170 \mathrm{~b} / \mathrm{min}$, they all suggest a predominance of the anaerobic system, because they are the characteristics of predominantly anaerobic efforts [9]. From the perspective of the energetic substrate, anaerobic effort may be: alactacid, 1 - $10 \mathrm{~s}$ (e.g. short sprints, runs 60- 100 m) and lactacid, $10-30 \mathrm{~s}$ (e.g. long sprints $200-$ $400 \mathrm{~m}$ running) [16]. It is appraised based on the maximum deficit calculated in $\mathrm{O}_{2}$ corresponding to the difference between the aerobic energy provided and the energy necessary to support effort, on maximum aerobic power corresponding to maximum $\mathrm{O}_{2}$ intake that ranges between 120 and $150 \%$, and on blood lactate, coming from the decomposition of lactic acid, representing the indicator that delimits the aerobic from the anaerobic energetic pathway [1]. The characteristics of the predominantly anaerobic efforts are as follows: alactacid, with a duration of 1 - 15 s, with very high intensity, with a misbalance between $\mathrm{O}_{2}$ supplies and demands (with the production of $\mathrm{O}_{2}$ debt, at the beginning of the effort and the payment of $\mathrm{O}_{2}$ debt after the end of the effort), with high heart rate (between 190 and 210 $\mathrm{b} / \mathrm{min}$ ), the energetic source being the phosphagen system; the carbohydrate metabolism participates to a reduced extent, the mechanical efficiency of 15 - 16\%; and lactacid with a duration of $10 \mathrm{~s}-1 \mathrm{~min}$, very high intensity, the same, with a misbalance between $\mathrm{O}_{2}$ supplies and demands (with the production of $\mathrm{O}_{2}$ debt, at the beginning of the effort and the payment of $\mathrm{O}_{2}$ debt after the end of the effort), high heart rate, the energetic source being the ATP and the mechanical efficiency of $15-16 \%$. This last type of effort is encountered frequently in the practice of amateur athletes, in both sporting games and the other forms of practicing physical exercises.

During physical effort, the cardiovascular system goes through both immediate alterations, caused by the body system in order to maintain homeostasis, and later alterations, in or to adapt to repeated physical efforts on a longer-term basis [14]. In order to maintain homeostasis during physical effort, the cardiovascular system has to make a rapid and adaptive intervention [11] the activity of the entire cardiovascular system features important modifications after physical effort, due to increased energy and oxygen need, as well as to the increased need of eliminating metabolic substances. By using the two adaptive mechanisms (a central mechanism represented by increased heart flow and a peripheral mechanism, represented by decreased vascular resistance and by the redistribution of local blood flows), the body can produce these modifications [1]. Once a physical exercise begins, the first adaptive mechanism in action is increased heart rate; at the same time, it is one of the easiest to measure cardiovascular parameters. Exercise tachycardia or increased heart rate is based on the stimulation of the sympathoadrenergic ergotropic 
mechanism. The intensity of the exercise, the gender and the training level influence the values of heart rate to be reached during physical effort [10]. $\mathrm{Hr}$ may also increase before actually beginning the effort. This is an anticipated response of the body by releasing the neurotransmitters called noradrenalin and adrenalin. During effort, $\mathrm{Hr}$ increases with the intensity of the exercise until it reaches a value considered maximum. This last value is considered the maximum heart rate $\left(\mathrm{Hr}_{\max }\right)$; scientific literature uses as unanimously accepted reference a value of $180 \mathrm{~b} / \mathrm{min}$ [2]. Over this value, heart flow and oxygen intake no longer increase. Each individual has their own $\mathrm{Hr}_{\text {max }}$, provided by gender and training level. The general formula for calculating $\mathrm{Hr}_{\text {max }}$, for healthy persons of up to 50 years old is the following: $\mathrm{Hr}_{\max }=220$ - age (years) [20].

\section{Material and method}

The purpose of the research is to monitor and record the acute modifications of Hr during effort in case of a repeated lactacid anaerobic effort. The research aims to relate $\mathrm{Hr}$ during effort, recorded during a lactacid anaerobic effort, to the maximum exercise heart rate recommended using the formula 220 age.

Research subjects. The research comprised 15 male subjects aged between 20 and 24, who volunteered to participate; all of them are amateur athletes who practice soccer in their free time.

The effort test chosen for standardizing effort was the 200-m race performed using the maximum potential of each subject. The $200-\mathrm{m}$ race was chosen because specialists have acknowledged it as an effort involving the lactacid anaerobic metabolic pathway. The subjects who were able to repeat the effort resumed the race four times, after a 4-minute break.

Equipment used. In order to monitor $\mathrm{Hr}$ during effort, the Polar Pro Team technology was used, because it provides both an instantaneous monitoring of the $\mathrm{Hr}$ and the possibility of downloading it later as graphs, within a program.

\section{Research findings}

In the following lines, I present the graphs illustrating $\mathrm{Hr}$ modification during exercise.

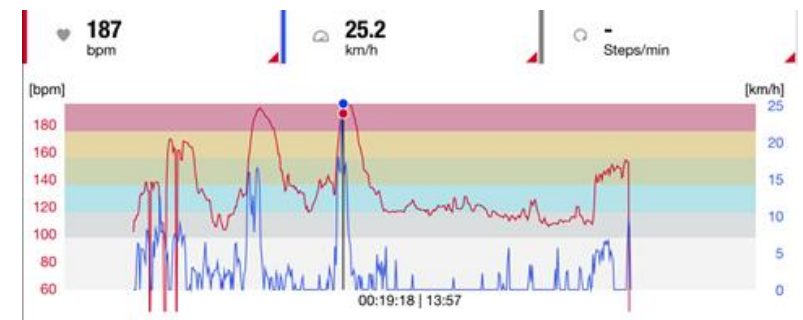

Figure No $1 \mathrm{Hr}_{\max }$ Subject no 1

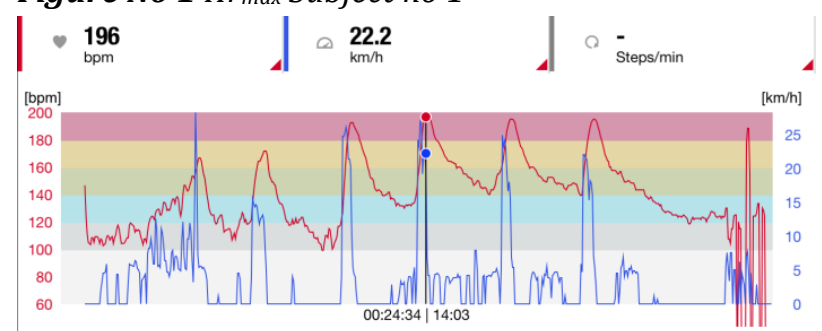

Figure No 2 Hr $_{\text {max }}$ Subject no 2

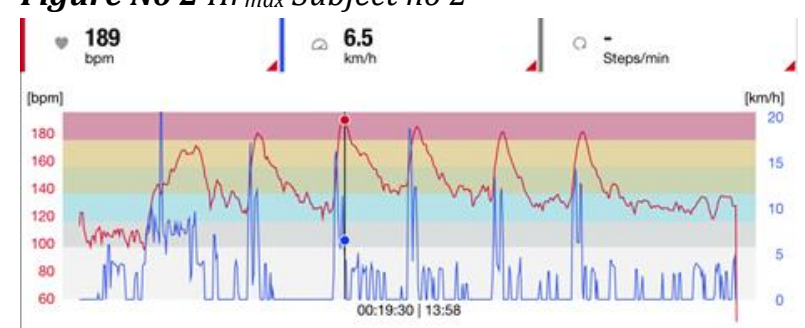

Figure No $3 \mathrm{Hr}_{\max }$ Subject no 3

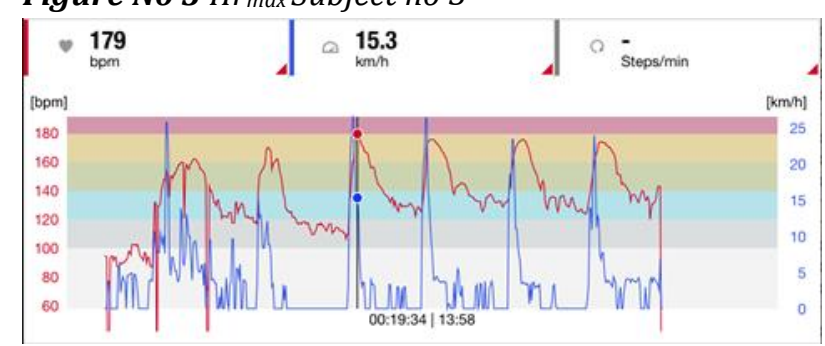

Figure No $4 \mathrm{Hr}_{\text {max }}$ Subject no 4

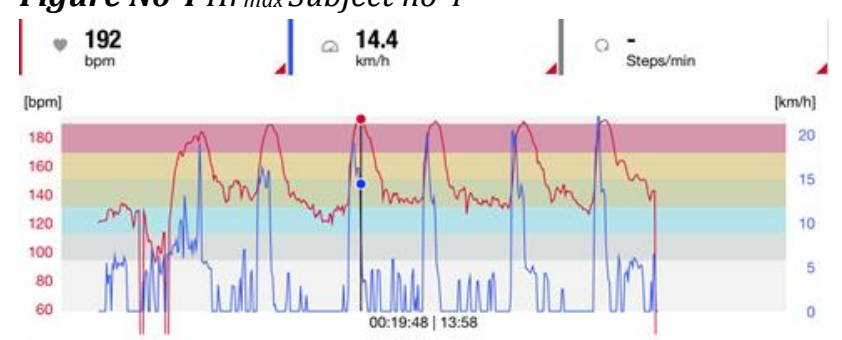

Figure No $5 \mathrm{Hr}_{\max }$ Subject no 5

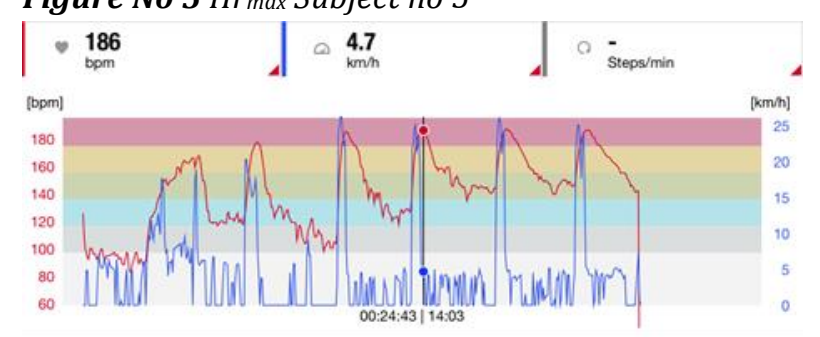

Figure No 6 Hr $r_{\text {max }}$ Subject no 6 


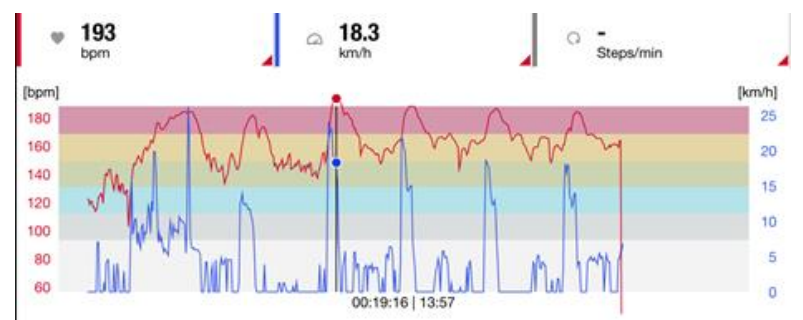

Figure No $7 \mathrm{Hr}_{\text {max }}$ Subject No 7

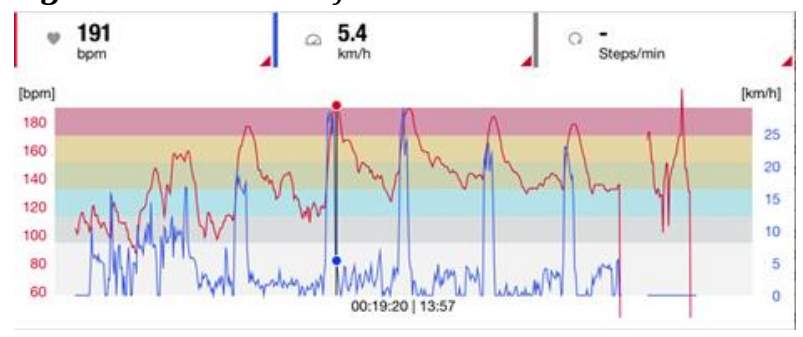

Figure No 8 Hrmax Subject No 8

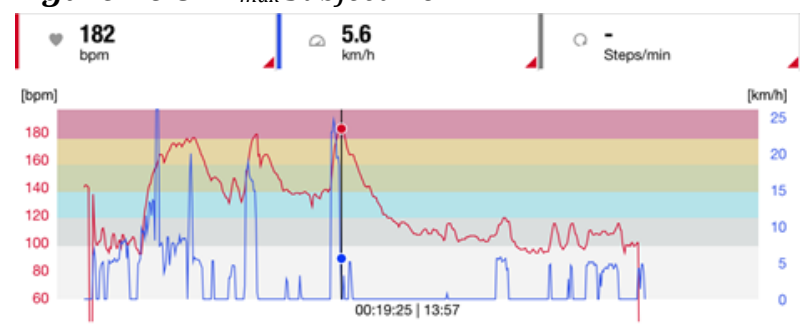

Figure No 9 Hrmax $_{\operatorname{mabject}}$ No 9

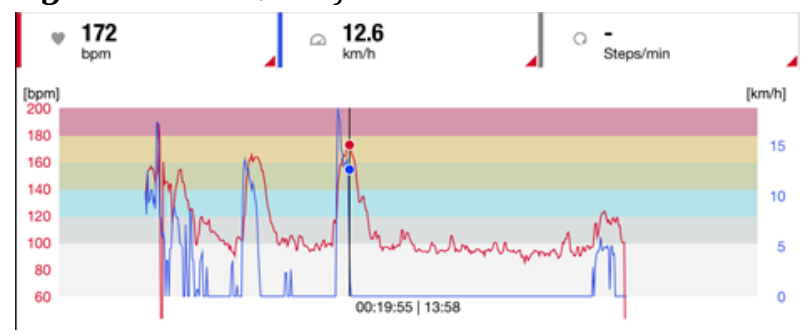

Figure No $10 \mathrm{Hr}_{\max }$ Subject No 10

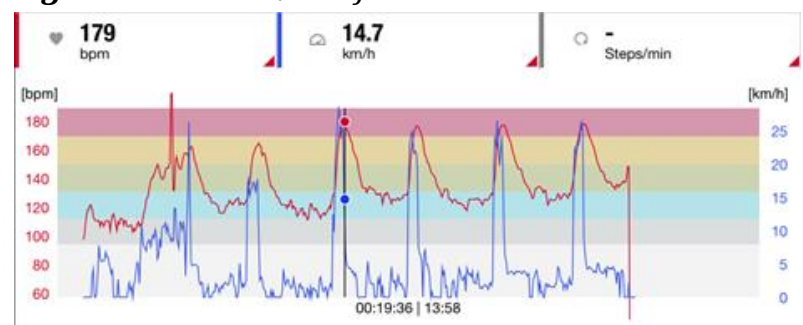

Figure No $11 \mathrm{Hr}_{\max }$ Subject No 11

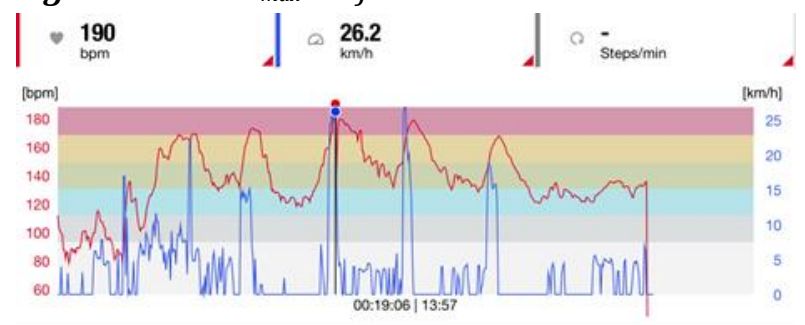

Figure No $12 \mathrm{Hr}_{\max }$ Subject No 12

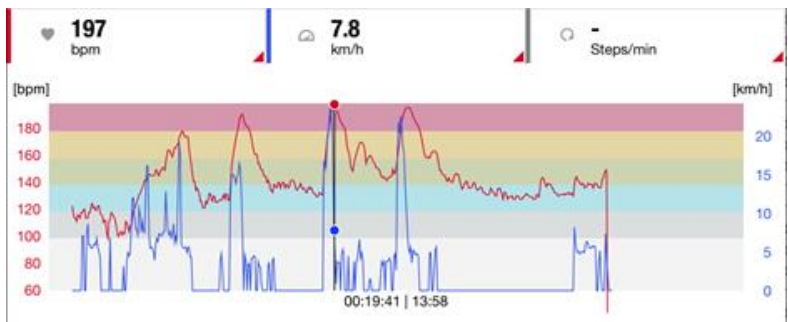

Figure No $13 \mathrm{Hr}_{\max }$ Subject No 13

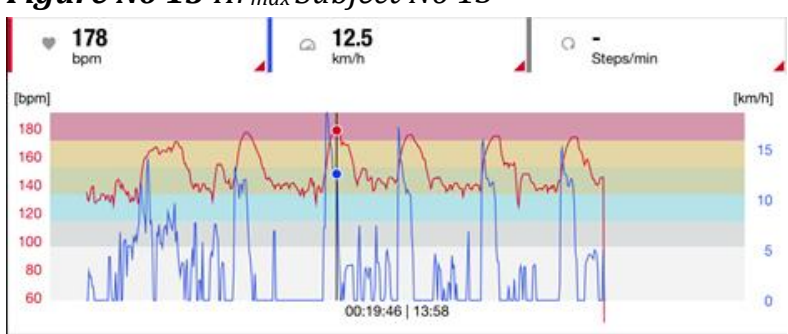

Figure No $14 \mathrm{Hr}_{\max }$ Subject No 14

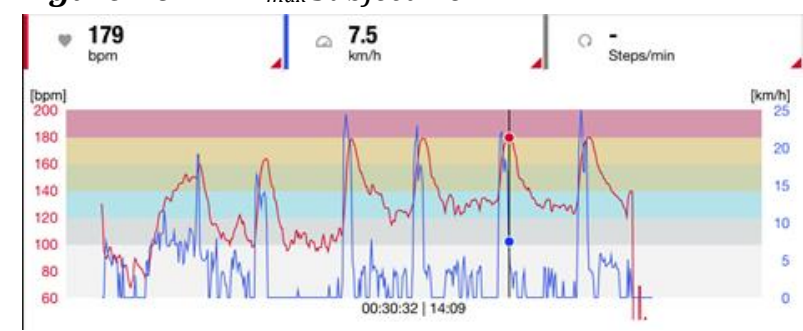

Figure No $15 \mathrm{Hr}_{\max }$ Subject No 15

The following table brings up together heart rates of the subjects $\left(\mathrm{Hr}_{\text {initial, }} \mathrm{Hr}_{\max }, \mathrm{Hr}^{3}\right)$ :

Table No I Heart rate of the subjects (Hrinitial, $\mathrm{Hr}_{\text {max, }}$ $H r^{3}$ )

\begin{tabular}{|l|l|l|l|}
\hline Subject & $\begin{array}{l}\text { Hrinitial } \\
\text { (beats/ } \\
\text { minute) }\end{array}$ & $\begin{array}{l}\text { Hr maxim } \\
\text { (beats/ } \\
\text { minute) }\end{array}$ & $\begin{array}{l}\text { Hr 3' } \\
\text { (beats/ } \\
\text { minute) }\end{array}$ \\
\hline No 1. & 116 & 187 & 129 \\
\hline No 2. & 110 & 196 & 139 \\
\hline No 3. & 115 & 189 & 138 \\
\hline No 4. & 108 & 179 & 135 \\
\hline No 5. & 121 & 192 & 147 \\
\hline No 6. & 118 & 186 & 139 \\
\hline No 7. & 125 & 193 & 160 \\
\hline No 8. & 113 & 191 & 137 \\
\hline No 9. & 108 & 182 & 123 \\
\hline No 10. & 105 & 172 & 108 \\
\hline No 11. & 115 & 179 & 133 \\
\hline No 12. & 111 & 190 & 136 \\
\hline No 13. & 109 & 197 & 141 \\
\hline No 14. & 119 & 178 & 147 \\
\hline No 15. & 110 & 179 & 126 \\
\hline & & & \\
\hline & & & \\
\hline
\end{tabular}




\section{Discussions}

In order to highlight the estimated differences between heart rate values according to the formula $\mathrm{Hr}_{\text {max }}=220$ age (in men) and the value of maximum heart rate recorded during physical effort, the following graphs were elaborated.

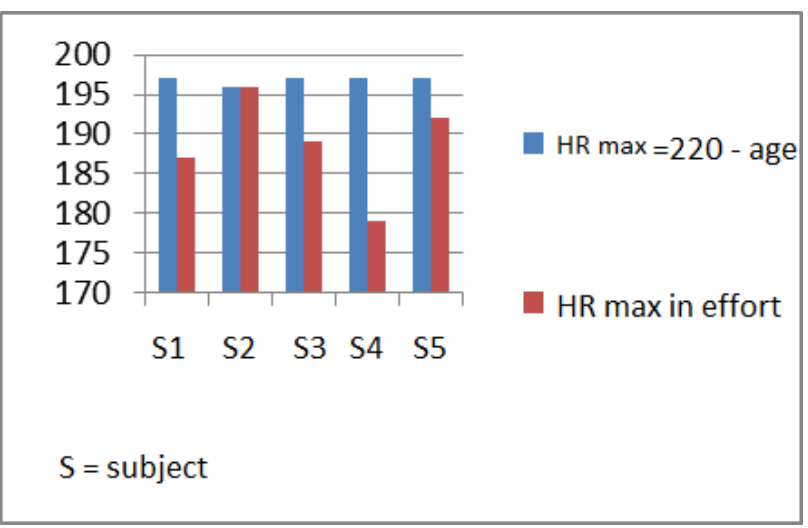

Figure No 16 Differences in the heart rate values of subjects 1-5

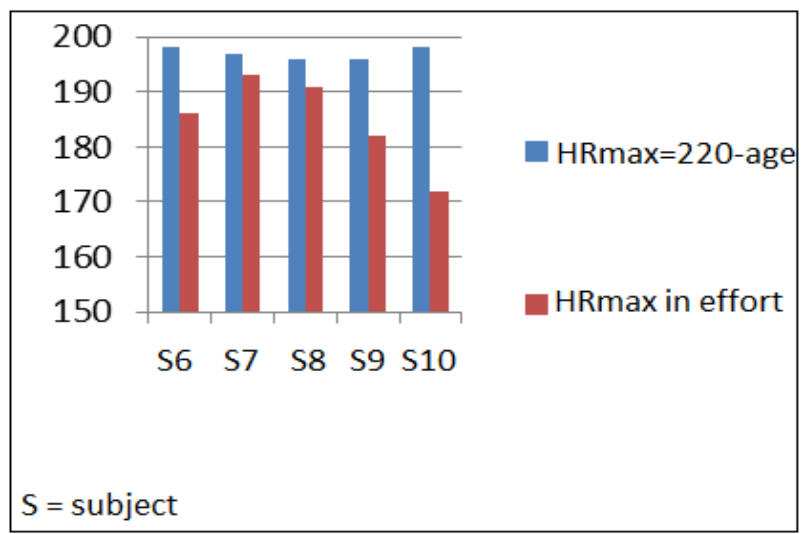

Figure No 17 Differences in the heart rate values of subjects 6-10

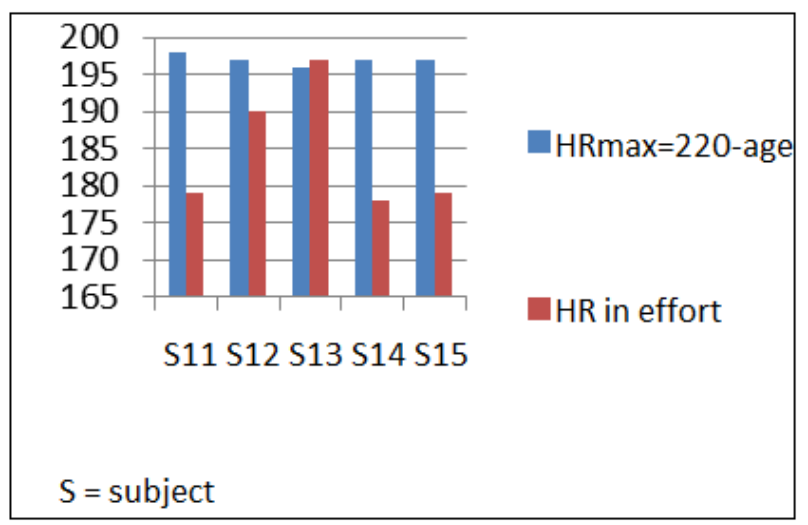

Figure No 18 Differences in the heart rate values of subjects 11-15
Figure No 16 shows that subject No 2 is the only one who recorded a maximum heart rate estimated using the formula (196 beats/ minute), while the other subjects scored sub-maximum values. Subjects No 6, 7, 8, 9 and 10 failed to reach the maximum heart rate provided by the formula. Figure No 18 illustrates that, from among all subjects, only subject No 13 managed to reach an over-maximum value, compared to $\mathrm{Hr} \max$ provided by the formula, during effort.

\section{Conclusions}

$\mathrm{Hr}_{\max }$, calculated using the formula 220 age, may be reached or even exceeded during lactacid anaerobic efforts by some of the amateur athletes. However, the findings of the study indicate that most athletes do not reach or do not exceed his value, even when they repeat the effort. The $\mathrm{Hr}$ restoring after 3 minutes is different from one athlete to another, probably depending on their training level or on other biological or chemical factors, which has also been highlighted by an amplitude of $52 \mathrm{~b} / \mathrm{min}$.

\section{References}

1. Apostol I. (2002). Curs de ergofiziologie, Al. I. Cuza University Press, Iași.

2. Billat V. (2003). Physiologie et methodologie de l'entraînement. Science et pratiques du sport, Edition De Boeck, Paris.

3. Carp C. (2003). Tratat de cardiologie (vol.2), Editura Medicală Națională, Bucharest.

4. Chelcea S., Mărginean I., Cauc I. (1998). Cercetarea sociologică - metode și tehnici, Editura Destin, Deva.

5. Cojocariu A. (2010). Fundamentele teoretice ale educației fizice și sportului, Editura Pim, Iași.

6. Habor A. (2008). Fiziologie (sângele, respirația, aparatul cardio-vascular), Editura University Press - Târgu-Mureș.

7. Hăulică I. (2009). Fiziologia umană, Editura Medicală, Bucharest.

8. Honceriu C. (2015). Fiziologia efortului fizic, Editura Pim, Iași. 9. Honceriu C. (2014). Fiziologia și ergofiziologia activităţilor fizice - handbook for master, Al. I. Cuza University Press, Iași. 10. Ionescu A. (1998). Contribuții privind validarea unor metode de determinare a capacității de efort anaerob la sportivii de performanță, Editura Univ. De Medicină și Farmacie Carmen Davila, Bucharest.

11. Mărcuș S. (1994). Inima și efortul fizic, Editura Gramar, Bucharest.

12. Millet G., Perrey S. (2005). Physiologie de l'exercice musculaire, Edition Ellipses, Paris.

13. Mitu F. (2008). Semiologie medicală. Aparatul respirator și cardiovascular, Editura Gr. T. Popa. UMF, Iași.

14. Mogoș V. (1990). Inima și efortul fizic, Editura Sport-Turism, Buchares. 
15. Noveanu L., Mihalaș G. (2005). Fiziologie practică - Vol. 2 Aparatul cardio-vascular, Aparatul respirator, Editura Mirton, Timișoara.

16. Plătăreanu V. (1940). Aparatul cardio-vascular, Editura „Bucovina”, Bucharest.

17. Străuț I. (1996). Efortul sportiv - efecte fiziologice, Editura Mirton, Timișoara.

18. Tache S., Staicu M. (2010). Adaptarea organismului la efort fizic (vol.1), Editura RISOPRINT, Cluj-Napoca.

19. Wilmore J., H., David L., Costill D., L. (2002). Physiologie du sport et de l'exercise, De Boeck Universite, Paris.

20. Yin Robert K., (2005). Studiu de caz - designul, analiza și colectarea datelor, translated by Alupoaie Valentin Editura Polirom, Iași.

Electronic references:

21. http://anatomie.romedic.ro/inima-cordul, accessed on 22 June 2017;

22. http://anatomie.romedic.ro/inima-cordul, accessed on 22 June 2017;

23. http://www.ymed.ro/revolutia-cardiaca/, accessed on 23 June 2017. 